Tamara Radjenovic ${ }^{1}$

Bojan Krstic ${ }^{2}$

University of Nis, Faculty of Economics
ORIGINAL SCIENTIFIC ARTICLE DOI:10.5937/ekonomika1702031R Received: April, 10, 2017 Accepted: May, 15, 2017

\title{
MEASURING INTELLECTUAL CAPITAL OF NATIONAL ECONOMIES ${ }^{3}$
}

\begin{abstract}
The importance of intellectual capital for creating and sustaining competitive advantage of firms has been well established and confirmed in theory and practice. Intellectual resources proved to be the most valuable resources in the process of value creation for various stakeholders. Starting from 1980s onwards, both researchers and practitioners have focused on finding the best solution for measuring intellectual capital in order to enable efficient management and reporting on intellectual capital. Soon after that, their attention switched from an organisational level to the level of cities, regions and national economies. The intellectual capital of a nation has become the most important driver of national wealth. Therefore, the aim of the paper is to examine the concept of national intellectual capital, as well as various measurement methodologies available for valuing the intangible resources of nations. Critical assessment of presented methodologies will give an overview to the policy makers how to identify and value the national intellectual capital in order to increase their national wealth and improve the well-being of their citizens.
\end{abstract}

Key words: national intellectual capital, knowledge economy, measurement methodologies, national wealth

JEL classification: 011,034

\section{МЕРЕЊЕ ИНТЕЛЕКТУАЛНОГ КАПИТАЛА НАЦИОНАЛНИХ ЕКОНОМИЈА}

\begin{abstract}
Апстракт
Значај интелектуалног капитала за стварање и одржавање конкурентске предности предузећа је добро утврђен и потврђен у теорији и пракси. Интелектуални ресурси су се показали као највреднији ресурси у процесу стварања вредности за различите стејкхолдере. Почев од 1980-их и истраживачи и практичари су се фокусирали на проналажење најбољег решења за мерење интелектуалног капитала како би омогућили ефикасно управљање и извештавање о
\end{abstract}

\footnotetext{
${ }^{1}$ tamara.radjenovic@eknfak.ni.ac.rs

${ }^{2}$ bojan.krstic@eknfak.ni.ac.rs

${ }^{3}$ The paper is a result of research within project 179066 funded by the Ministry of Education, Science and Technological Development of the Republic of Serbia
} 
интелектуалном капиталу. Убрзо затим, нихова пажња се са организационог нивоа померила на градове, регионе и начионалне привреде. Национални интелектуални капитал је постао најзначајнији покретач националног богатства. У том смислу, ичиљ овог рада је да истражси кониепт националног интелектуалног капитала, као и различите расположиве методологије за мерење нематеријалних ресурса на нивоу начионалних привреда. Критичка очена презентованих методологија ће дати увид креаторима политика како да идентификују и вреднују национални интелектуални капитал у ичиљу повећања њиховог наџионалног богатства и побољиања добробити њихових грађана.

Кључне речи: национални интелектуални капитал, економија знања, методологије мерења, национално богатство

\section{Introduction}

Numerous technological advances and globalization have altered the sources of value creation and growth. In the new era - the knowledge era - the emphasis has been put on the knowledge resources as the primary production factors which have replaced the traditional production factors, such as a land, labour and capital. Only a few decades ago in 1978, the $80 \%$ of the value of corporations was attributed to the tangible assets, while $20 \%$ was ascribed to intangible assets (Sullivan \& Sullivan, 2000, p. 328). In contemporary circumstances, this proportion has changed in favour of intangible assets, and now the intangible, intellectual resources have the dominance over tangible assets - 87\%:13\% (Ocean Tomo, 2015).

The importance of intellectual resources in the process of value creation has been well recognised by the knowledge intensive firms starting from 1980s onwards. The market value of these firms was far above their book value, and this difference was attributed to the intellectual capital. As the main components of the intellectual capital at the micro level, the human, structural and relational capital, were identified. Once, the intellectual resources proved to be important and valuable for the competitiveness of firms, academic researchers and practitioners have been interested in the role they have in the process of wealth creation and competitiveness of cities, regions and nations. Since then numerous studies have been conducted focusing on valuing national intellectual capital by replicating microeconomic models for measuring intellectual capital (Lazuka, 2012, p. 8).

But in order to efficiently manage intellectual capital of nations, improve the competitive position of a country in the international market, and hence improve the living conditions of their citizens, it is necessary to better understand the concept of intellectual capital of nations, its categorization, and measuring approaches. Bearing all this in mind, the aim of this paper is to give the comprehensive analysis of the concept of intellectual capital at the national economy level, theoretical examination of its relationship and contribution to the economic growth from the growth theories, and critical analysis of different methodologies available for measurement these intangible resources.

The paper is structured as follows. The introduction gives the brief overview of the subject of the paper and describes the authors' motivation for choosing this topic. The first section is devoted to the macroeconomic foundations of intellectual capital. Afterwards, the 
role of intellectual capital in economic growth literature will be studied. The subsequent section will critically address several methodologies for the measurement of the intellectual capital of nations. Finally, the conclusion will sum up the main findings.

\section{The Macroeconomic Foundations of Intellectual Capital}

The rapid development of information and communication technologies brings substantial benefits which are used for intensifying the dynamics of economic development of countries and regions, thus leading to the effective transformation of knowledge, skills, talents and know-how of individuals in profit and non-profit organisations and enterprises. Contemporary business conditions require workers with diverse intellectual agility and competences needed for the critical thinking in the technologically intensive environment (Krstić \& Vukadinović, 2009). Besides, these knowledge workers are necessary for creating potentials and new resources in order to increase the wealth of nations.

Therefore, the competitive advantage of nations and their wealth is no longer based on comparative advantages they have, but on competitive advantages they create (Rakić \& Rađenović, 2016). Constant technological changes and processes of globalization and liberalization have directed the transformation of industrial economies into knowledge economies by shifting the focus of natural resources to the knowledge and innovation (Laroche et al., 1999, p. 88). In this new economy, knowledge, innovations and networking have become the basic drivers of a country's economic prosperity, and hence the wealth of nations depends on the level of knowledge and its effective and efficient usage (Krstić \& Vukadinović, 2009, p. 460).

Although the notion of intellectual capital is mostly associated with the microeconomic and management literature, its roots can be easily found in the macroeconomic and growth literature as well. Originally, the term intellectual capital was ascribed to Machlup (1962), who coined it in order to explain the importance of knowledge for the growth and development of firms and nations. It has been well recognised that knowledge, i.e. intellectual capital occupies the central place in the process of economic growth and development in the knowledge economy (Krstic \& Stanišić, 2013, p. 153).

The concept of intellectual capital of a country involves the combination of various variables which can be helpful for identification, encompassing and management of its invisible intangible wealth. This concept has to provide the basis for measuring and monitoring of national (regional) intellectual resources, determine their impact on the previous development and necessary steps of macroeconomic management in guiding economic prosperity (Krstić \& Vukadinović, 2009). Malhotra (2000) highlights that policy makers of national economies development policies are trying to find consistent and reliable methodology to measure knowledge assets in order to comprehend their relations with the future performance.

The concept of national intellectual capital involves the implicit value of individuals, firms, institutions, communities and regions that are the current and potential sources of wealth creation (Edvinsson \& Stenfelt, 1999; Bontis, 2004). The intellectual capital of a country represents its capability to transform knowledge and other intangible assets into wealth (Bradley, 
1997a; 1997b). The intellectual capital of a nation or society reflects the intellectual capital of its individuals and organizations (Edvinsson, 2002). The wealth of a nation or a country can be viewed as the combination of the financial wealth of a country represented in gross domestic product per capita and national intellectual capital (Figure 1). The notion of national intellectual capital is based on the elements of the microeconomic concept of intellectual capital, that is, human capital and structural capital. Numerous studies have replicated measurements from micro level to the level of nations (Edvinsson \& Stenfelt, 1999; Malhotra, 2003; Bontis, 2004; Andriessen \& Stam, 2004; Hervas-Oliver \& Dalmau-Porta, 2007; Weziak, 2007; Ståhle \& Bounfour, 2008; Lin \& Edvinsson, 2008; 2011; Stam \& Andriessen, 2009; Lazuka, 2012). Moving from the level of a firm to the level of a nation is based on a premise that intellectual capital is an important driver of productivity and competitiveness of a country as it is for a firm (Labra \& Sánchez, 2013). The intellectual capital of nations is a concept that applies the principles of intellectual capital measurement and management on a macroeconomic level in order to direct the future perspectives of economic developments (Andriessen \& Stam, 2004, p. 11). However, the complexity of intellectual capital valuation makes it impossible to simply translate micro models to the national level (Lin \& Edvinsson, 2011), since the assessment of hidden value for countries is more difficult than for firms (Käpylä et al., 2012).

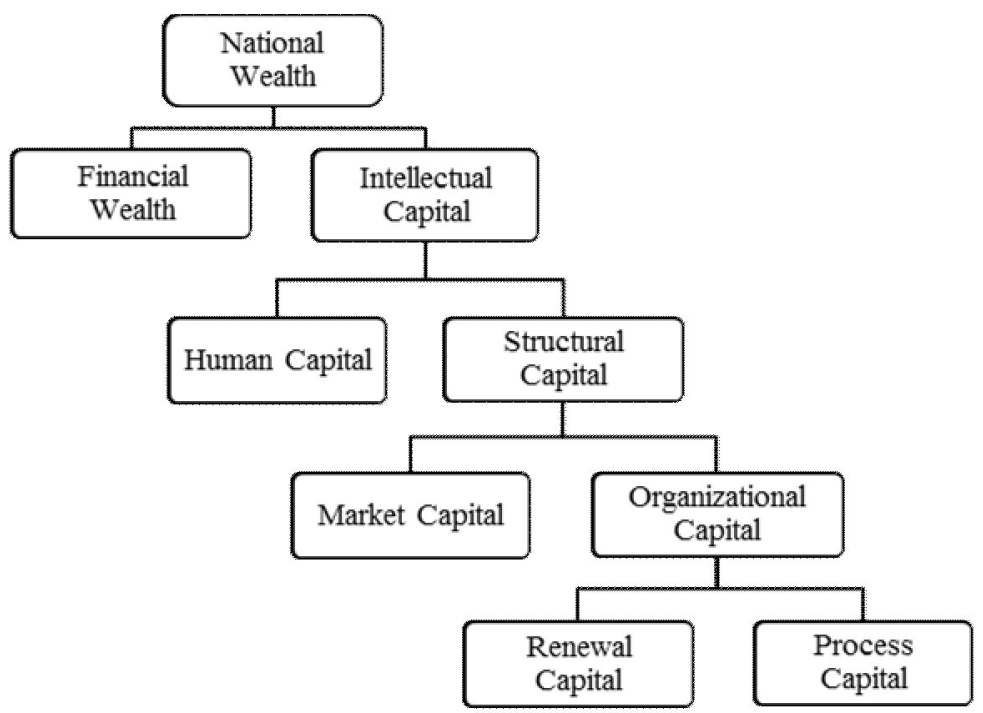

Figure 1. The Intellectual Capital of Nations

Source: Bontis (2005, p. 115)

According to Bontis (2004) the national intellectual capital is comprised of four components: human capital ("knowledge, education and competencies of individuals in realizing national tasks and goals" (p. 20)), market capital ("intellectual capital embedded in national intra-relationships" (p. 23)), renewal capital ("nation's future intellectual wealth" (p. 24)) and process capital ("non-human storehouses of knowledge in a nation which are embedded in its technological, information and communications systems" (p. 21)). But, there is not a unique classification of intellectual capital components among researchers and "the content of intellectual capital and its different components (i.e. human/relational/market/ 
structural/process/renewal) remains quite vague" (Käpylä et al., 2012, p. 346). Different studies employ different classifications and this puts considerable obstacle for international comparisons. Namely, the basic enticement for measuring the intellectual wealth of nations is to gain insight into the relative advantage of countries, thus enabling the development of policies directed toward improving future economic performance (Andriessen \& Stam, 2004, p. 11). This is possible by comprehending the relationships and synergies that can increase the value of each sub-component of intellectual capital (Choo \& Bontis, 2002).

Before assessing different measurement methodologies, the role of the intellectual capital in the process of wealth creation will be explained through the growth literature.

\section{Intellectual Capital in the Growth Literature}

According to neoclassical economic theory, knowledge as the central part of intellectual capital has always been the contributing factor of economic relationships whose value has been expressed through the price of labour (Vlada RS, 2011, pp. 2-3). Due to the law of diminishing returns, the theoretical explanation of economic growth was based on the extensive usage of natural resources and labour, on one hand, and changes in technology and organization of production, on the other hand, where these changes were observed as an exogenous factor of economic development (Vlada RS, 2011, p. 3). Namely, the costs and benefits of the development and application of new technologies were not incorporated in the growth model, since it was believed that they are the result of non-economic factors.

Therefore, the Solow's (1957) growth model was unable to explain the major determinants of productivity growth (Viedma Marti \& Cabrita, 2012, p. 18), as the huge amount of growth was attributed to the Solow's residual, i.e. the part of output growth that cannot be accounted for by growth in the primary production factors (labour and capital), but by other exogenous factor that have influence on growth. This residual factor accounted for $85 \%$ of the output growth that could not be explained by changes in the growth of physical inputs (Wilson \& Briscoe, 2004, p. 38).

Hence, the basic Solow's model can be augmented by incorporating different types of labour (for example, different lengths of schooling, qualifications, occupations, etc.) (Wilson \& Briscoe, 2004, p. 40), i.e. stock of human capital as an additional explanatory variable in the model, so that production function has the following form (Mankiw et al., 1992, p. 416):

$Y_{t}=K_{t}^{\alpha} H_{t}^{\beta}\left(A_{t} L_{t}\right)^{1-\alpha-\beta}$

Where: $\alpha+\beta<1, Y$ - output, $K$ - capital, $L$ - labour, $A$ - the level of technology, $H-$ stock of human capital, $t-$ time.

This form allows to easily establish the relationship with current and past investments in knowledge, since these investments in intellectual capital generate current output, holding tangible inputs constant (Wilson \& Briscoe, 2004, p. 40). Thus, the stock of human capital determines the income per capita, whereas differences in saving, education, and population growth explain cross-country differences in income per capita (Mankiw et al., 1992, p. 433).

Based on the critics of the traditional neoclassical growth model, the new theories emerged which observed these other factors as endogenous. These endogenous growth models focus on the importance of knowledge and innovations for the long-term economic growth (Romer, 1986; 1987; 1990; 1994; Lucas, 1988; Pelinescu, 2015). Rapid changes in 
economic and everyday life, as the consequence of the increase of scientific and professional knowledge, have led to the augmentation and revision of the economic growth model to incorporate technological changes. The important proposition of the new growth model is the fact that technology, i.e. knowledge, i.e. intellectual capital is not subject to the law of diminishing returns (Vlada RS, 2011, p. 3).

Opposite to the neoclassical growth model which implies the convergence in the gross domestic product per capita, that is, the convergence of the countries at different level of economic development, the endogenous growth models arose as the result of divergence in the gross domestic product per capita of different countries, and rejecting the premise of diminishing returns (Cvetanović \& Novaković, 2014, p. 111). Namely, the theorists of the endogenous growth consider the state of imperfect competition as real, and thus economies do not need to unconditionally achieve the stable rate of equilibrium growth, whereas the growth at rates higher than equilibrium is sustainable due to the increasing returns (Cvetanović \& Despotović, 2014, p. 13). According to Romer (1986), "the long-run growth is driven primarily by the accumulation of knowledge by forward-looking, profit-maximizing agents" (p. 1003).

Endogenous growth models can be divided into three broad groups (Mervar, 1999; 2003; Cvetanović \& Despotović, 2014; Cvetanović \& Novaković, 2014):

- Models based on the externalities, in which the departure from the assumption of diminishing returns is linked to the effects of learning by doing (Arrow, 1962), spillovers of knowledge (Romer, 1986), and human capital accumulation, either through schooling or learning-by-doing (Lucas, 1988);

- Models based on the research and development activities, in which building upon the Schumpeter's ideas (1942) the drivers of economic growth are the results of research and development activities. Romer's dynamic model (1990) is characterised by the monopolistic competition and existence of research sector that uses human capital and existing stock of knowledge to produce new knowledge. Hence, the basic implication of this model is that an economy with a larger stock of human capital will achieve faster growth (Romer, 1990, p. S99).

- $A K$ growth models, in which the economic growth is a result of capital accumulation, where capital can have different forms, including human and physical capital (Rebelo, 1991). In these models $A$ does not represent the level of technology, but constant that indicates the linear relationship between produced output and capital (Mervar, 2003, p. 383), where the marginal product of capital has to be above specific lower bound in order individuals to endlessly accumulate capital and investments never to exhibit the diminishing returns (Cvetanović \& Novaković, 2014, p. 117).

The important implication of the endogenous growth models is that economies with a larger extent of savings and investments grow faster in the long run, and hence, policies that have influence of the rate of savings are more important for economic prosperity, since they can contribute to the continuous increase of growth (Mervar, 1999, p. 12). Additionally, governments orientated toward supporting the economic growth and development, have to design macroeconomic policies that stimulate investments in the research and development of new ideas, as well as to subsidize the accumulation of total human capital (Romer, 1990, p. S99). The intellectual capital theory is rooted in these endogenous growth models, where 
the value of enterprises and wealth of cities, regions and nations is generated from human, structural and relational capital (Kolaković, 2003, p. 925).

\section{Measurement Methodologies at Macro Level}

During the last two decades, research and studies on national intellectual capital have shaped several measurement tools to capture the impact of intellectual capital on the economic performance of a country. Developed methodologies seems to differ mainly in the fact that some use secondary data in order to make international comparison of the certain national intellectual capital indicators, while other focus on primary data with the objective to use the obtained information about intellectual capital for the internal strategic guidance perspective (Salonius \& Lönnqvist, 2012, p. 333) and decision making on national intellectual capital (Labra \& Sánchez, 2013, p. 585). In general, it is possible to identify two approaches in classifying and measuring intellectual capital (Labra \& Sánchez, 2013, p. 587): one stemming from the research of intangibles by academics and professionals, and other developed by international organizations aiming at studying competitiveness, innovative capacity and development at the level of national economies.

The first attempts of valuing national intellectual capital are linked to Sweden and research conducted by Caroline Stenfelt and Madeleine Jarehov under the supervision of Leif Edvinsson in 1996 (Edvinsson \& Stenfelt, 1999). These authors attempted to quantify the factors which determine the future success of Sweden by employing the Skandia Navigator. After presenting first prototype of the intellectual capital of nations, Leif Edvinsson and his team have worked continuously on the improvement of their research and they have identified five key indicators for determining position, evolution, speed and direction of future development of national intellectual capital: innovations, external relations and exchange of knowledge, human capital, information technologies and entrepreneurship (Edvinsson \& Stenfelt, 1999, pp. 25-28).

Deriving from this study, and with the help of Edvinsson and Stenfelt, similar research has been conducted in Israel during 1997 by the Edna Pasher PhD and Associates (Pasher \& Shachar, 2005). Their research project was divided in four phases (Pasher \& Shachar, 2005, p. 141):

- The first phase was orientated toward shaping the vision of a country to serve as a research benchmark;

- The second phase was devoted to the core competencies needed for the vision achievement;

- The third phase was orientated toward determining the key success factors for each competence; and

- The forth phase was oriented toward determining the indicators for each factor.

The core competences, key success factors and indicators were clustered, according to Skandia model, into four categories: renewal and development capital, human capital, market capital, and process capital (Pasher \& Shachar, 2005, p. 142). After that numerous studies have been conducted in different countries and regions. Some of them are: Bontis (2004) for the Arab region; Bounfour (2003), Edvinsson and Bounfour (2004), Andriessen and Stam (2004), Pulic (2005), Weziak (2007) for the EU countries; Lin 
and Edvinsson (2008) for the Nordic countries; Lin and Edvinsson (2011) for 40 countries; Pöyhönen and Smedlund (2004) for a cluster in the eastern part of Finland; Schiuma et al. (2008) for the Italian regions; Huggins et al. (2014) for 546 regions; etc.

One of the interesting study is certainly study conducted by Andriessen and Stam (2004) for the EU countries. These authors developed Intellectual Capital Monitor for the measurement of intangibles comprising of three components: human, structural and relational capital, and three different perspectives: assets, investments and effects, in order to highlight the significance and changes between past, present and future developments. Their $3 \times 3$ matrix is filled with 38 performance indicators for measuring the intellectual capital. Based on the research results they concluded that (Andriessen \& Stam, 2004, pp. 17-18):

- Leading economies have substantially greater value of both human and structural capital;

- Investments in intellectual capital pay off, since there is strong and significant correlation between investments and assets;

- Low values of intellectual capital assets seem to be a guarantee for low intellectual productivity.

Another important study is the one conducted by Bontis (2004) for the 10 countries from the Arab region. This study is also based on Skandia model where intellectual capital encompasses four key components: human capital, process capital, market capital and renewal capital. Thus, National Intellectual Capital Index represents the average value of four partial indexes: National Human Capital Index (seven indicators), National Renewal Capital Index (seven indicators), National Market Capital Index (three indicators), and National Process Capital Index (eight indicators). Once, these indexes were calculated the structural equation map was developed and the links among indexes were established. Based on the conceptual map the national wealth of Arab countries was directly determined by human and market capital, while process capital had direct influence on renewal and market capital, renewal capital directly influenced human capital, and human capital also had direct influence on process capital (Bontis, 2005, p. 131). The results provided on this structural map are important since "they clearly indicate that the weighting of components may be based on the analysis of inter-relational dependencies rather than speculative choices (Ståhle, 2008, p. 10).

Also, Edvinsson and Bounfour (2004) developed the IC d-VAL ${ }^{\circledR}$ for measuring intellectual capital of nations and regions. This measure is comprised of four dimensions - resources, processes, assets and outputs. For each dimension a benchmarking process with the best performers is conducted, and performance indexes and composite index per country are calculated. These authors applied the proposed framework for benchmarking the performance of EU countries.

As mentioned earlier in the study, second approach focuses only on partial indicators within different methodologies proposed by numerous international institutions, such as: the World Bank - Knowledge Assessment Methodology, the INSEAD - Global Innovation Index, the World Economic Forum - Global Competitiveness Index, the International Institute for Management Development - World Competitiveness Index, the United Nations Development Programme - Human Development Index, the European Union - Innovation Union Scoreboard, the Organization for Economic Cooperation and Development - Science, Technology and Industry Outlook, etc. These models report rankings of countries similar to those proposed by previously described models, but opposed to the academic models which 
determine the intellectual capital as an independent factor comprising only indicators of intangible assets, the international organization models combine the indicators of tangible and intangible assets to determine competitiveness, innovation capacity, or development of a country without clear identification of intellectual capital (Labra \& Sánchez, 2013, p. 588).

However, these international organization models are widely accepted by policy makers and much more used then models exclusively dealing with intellectual capital. This is due to the fact that policy makers are not yet familiar with the concept of intellectual capital, even though the elements of national intellectual capital such as national brand or competence level are highly valued (Salonius \& Lönnqvist, 2012). As the knowledge and acceptance of composite indexes grow among policy makers, the importance of presented models for understanding and managing intellectual capital of national economies will grow as well. Nonetheless, no consensus yet exists on the evaluation models or the indicators.

\section{Conclusion}

During last decades intellectual capital has become the most important source of value, wealth and prosperity. Expansion of knowledge based business activities and technological revolution have led to the economic transformation at micro and macro level, and hence raw materials and labour are no longer the main source of value creation, but capabilities of creating and using the knowledge resources.

These intangible assets are important for companies and their stakeholders, as well as for the macroeconomic policy makers. Namely, intellectual resources are principal source of competitive advantage which must be identified, measured and controlled in order to obtain efficient management in companies, and besides, these resources are key drivers of growth and competitiveness in an economy and their measurement is crucial for designing and implementing public policies.

National intellectual capital incorporates hidden values of individuals, firms, institutions, communities and regions which are the source of wealth, competitiveness and productivity of nations. These hidden values represent the base for the future development, and hence in is necessary to map the intellectual resources in a country in order to systematically monitor the development of national intellectual capital. Therefore, it is necessary to find a consistent and reliable measure of the national intellectual capital that can help governments to improve the management of the intangible resources which are key determinants of the success of an economy.

This paper addressed numerous models for measuring the intellectual capital of national economies. Although the measurement of national intellectual capital is widely leaned on the microeconomic concept of intellectual capital measurement, consensus does not exist among researches about key indicators which best capture the value of intellectual capital of nations. Namely, different researchers differently group indicators within partial indexes and this undermines the possibility of comparative analysis of the intellectual capital of different countries.

The other issue is related to measurement and metrics, since even when the model is well structured and consistent, it does not provide straightforward guidelines for valuing the relationship among the subcomponents of intellectual capital and hence it is hard to ensure the validity of the index (Ståhle, 2008, p. 7). Additionally, the suggested models combine 
different indicators into a composite index based on a hypothetical weights instead of the established relations between the subcomponents.

Bearing all this in mind, future research should be focused on resolving several issues in order to adequately capture the value of intellectual capital and its contribution to the economic growth and national wealth. First, the clear definitions and classifications of intellectual capital components should be determined. Then, the relationships between intellectual capital components should be clearly established and based on these relationships the proper weights should be determined to each subcomponent. Finally, when determining the contribution of intellectual capital to the economic growth other non-intellectual capital factors should be taken into account as well.

\section{References}

Andriessen, D. G., \& Stam, C. D. (2004). The Intellectual Capital of the European Union. Diemen, Netherlands: Centre for Research in Intellectual Capital, INHOLLAND University of professional education, de Baak - Management Centre VNO-NCW.

Arrow, K. J. (1962). The Economic Implications of Learning by Doing. The Review of Economic Studies, 29(3), 155-173. Преузето ca http://www.jstor.org/ stable/2295952

Bontis, N. (2004). National Itellectual Capital: A United Nations Initiative for the Arab Region. Journal of Intellectual Capital, 5(1), 13-39. doi:10.1108/14691930410512905

Bontis, N. (2005). National Intellectual Capital Index: The Benchmarking of Arab Countries. In Intellectual Capital for Communities: Nations, Regions, and Cities (pp. 113-138). Burlington, MA: Elsevier Butterworth-Heinemann.

Bounfour, A. (2003). The IC-dVAL Approach. Journal of Intellectual Capital, 4(3), 396-413. doi:10.1108/14691930310487833

Bradley, K. (1997a). Intellectual Capital and the New Wealth of Nations. Business Strategy Review, 8(1), 53-62. doi:10.1111/1467-8616.00007

Bradley, K. (1997b). Intellectual Capital and the New Wealth of Nations II. Business Strategy Review, 8(4), 33-44. doi:10.1111/1467-8616.00046

Choo, C. W., \& Bontis, N. (Eds.). (2002). The Strategic Management of Intellectual Capital and Organizational Knowledge. Oxford, UK: Oxford University Press.

Cvetanović, S., \& Despotović, D. (2014). Znanje kao komponenta ljudskog kapitala u modelima ekonomskog rasta. Škola biznisa(1), 1-17. doi:10.5937/skolbiz1-5976

Cvetanović, S., \& Novaković, I. (2014). Inovativnost i održiva konkurentnost. Niš: Univerzitet u Nišu, Filozofski fakultet.

Edvinsson, L. (2002). Corporate Longitude: What You Need to Know to Navigate the Knowledge Economy. London, UK: Financial Times Prentice Hall.

Edvinsson, L., \& Bounfour, A. (2004). Assessing National and Regional Value Creation. Measuring Business Excellence, 8(1), 55-61. doi:10.1108/13683040410524748 
Edvinsson, L., \& Stenfelt, C. (1999). Intellectual Capital of Nations - for Future Wealth Creation. Journal of Human Resource Costing \& Accounting, 4(1), 21 33. doi:10.1108/eb029051

Hervas-Oliver, J. L., \& Dalmau-Porta, J. I. (2007). Which IC Components Explain National IC Stocks? Journal of Intellectual Capital, 8(3), 444-469. doi:10.1108/14691930710774867

Huggins, R., Izushi, H., Prokop, D., \& Thompson, P. (2014). Regional Competitiveness, Economic Growth and Stages of Development. Proceedings of Rijeka Faculty of Economics: Journal of Economics and Business, 32(2), 255-283.

Käpylä, J., Kujansivu, P., \& Lönnqvist, A. (2012). National Intellectual Capital Performance: A Strategic Approach. Journal of Intellectual Capital, 13(3), 343362. doi:10.1108/14691931211248909

Kolaković, M. (2003). Teorija intelektualnog kapitala. Ekonomski pregled, 54(11-12), 925-944.

Krstić, B., \& Stanišić, T. (2013). The Influence of Knowledge Economy Development on Competitiveness of Southeastern Europe Countries. Industrija, 141(2), 151168. doi:10.5937/industrija41-4000

Krstić, B., \& Vukadinović, D. (2009). Valorizovanje resursa znanja - metodologija nacionalnog indeksa intelektualnog kapitala. In Z. Arandjelović, Regionalni razvoj $i$ demografski tokovi zemalja jugoistočne Evrope (pp. 459-468). Niš: Univerzitet u Nišu, Ekonomski fakultet.

Labra, R., \& Sánchez, P. (2013). National Intellectual Capital Assessment Models: A Literature Review. Journal of Intellectual Capital, 14(4), 582-607. doi:10.1108/ JIC-11-2012-0100

Laroche, M., Mérette, M., \& Ruggeri, G. C. (1999). On the Concept and Dimensions of Human Capital in a Knowledge-Based Economy Context. Canadian Public Policy - Analyse de Politiques, 25(1), 87-100.

Lazuka, V. (2012). National Intellectual Capital: Concept and Measurement. Master Thesis. Lund, Sweden: Lund University, School of Economics and Management.

Lin, C. Y.-Y., \& Edvinsson, L. (2008). National intellectual capital: comparison of the Nordic countries. Journal of Intellectual Capital, 9(4), 525-545. doi:10.1108/14691930810913140

Lin, C. Y.-Y., \& Edvinsson, L. (2011). National Intellectual Capital: A Comparison of 40 Countries. New York: Springer.

Lucas, R. E. (1988). On the Mechanics of Economic Development. Journal of Monetary Economics, 22(1), 3-42.

Machlup, F. (1962). The Production and Distribution of Knowledge in the United States. Princeton, New Jersey: Princeton University Press.

Malhotra, Y. (2000). Knowledge Assets in the Global Economy: Assessment of National Intellectual Capital. Journal of Global Information Management, 8(3), 5-15.

Malhotra, Y. (2003). Measuring Knowledge Assets of a Nation: Knowledge Systems for Development. Research Paper prepared for UN Advisory Meeting of the 
Department of Economic and Social Affairs Division for Public Administration and Development Mangement. New York: United Nations.

Mankiw, G. N., Romer, D., \& Weil, D. N. (1992). A Contribution to the Empirics of Economic Growth. The Quarterly Journal of Economics, 407-437.

Mervar, A. (1999). Pregled modela i metoda istraživanja gospodarskog rasta. Privredna kretanja i ekonomska politika, 9(73), 20-61.

Mervar, A. (2003). Esej o novijim doprinosima teoriji ekonomskog rasta. Ekonomski pregled, 54(3-4), 369-392.

Ocean Tomo. (2015). Intangible Asset Market Value Study. Retrieved April 17, 2017, from Ocean Tomo: http://www.oceantomo.com/intangible-asset-market-value-study/

Pasher, E., \& Shachar, S. (2005). The Intellectual Capital of the State of Israel. In A. Bounfour, \& L. Edvinsson (Eds.), Intellectual Capital for Communities: Nations, Regions, and Cities (pp. 139-149). Oxford, UK: Elsevier ButterworthHeinemann.

Pelinescu, E. (2015). The Impact of Human Capital on Economic Growth. Procedia Economics and Finance, 22, 184-190. doi:10.1016/S2212-5671(15)00258-0

Pöyhönen, A., \& Smedlund, A. (2004). Assessing Intellectual Capital Creation in Regional Clusters. Journal of Intellectual Capital, 5(3), 351-365. doi:10.1108/14691930410550345

Pulic, A. (2005). Value Creation Efficiency at National and Regional Levels: Case Study - Croatia and the European Union. In A. Bounfour, \& L. Edvinsson (Eds.), Intellectual Capital for Communities: Nations, Regions, and Cities (pp. 197211). Oxford, UK: Elsevier Butterworth-Heinemann.

Rakić, B., \& Rađenović, T. (2016). Dinamička analiza konkurentnosti privrede Srbije. In J. Đurović Todorović, \& M. Radosavljević, Antikrizne politike i postkrizni procesi: Izazovi ekonomske nauke (pp. 123-136). Niš: Univerzitet u Nišu, Ekonomski fakultet.

Rebelo, S. (1991). Long-Run Policy Analysis and Long-Run Growth. Journal of Political Economy, 99(3), 500-521. Retrieved from http://www.jstor.org/ stable/2937740

Romer, P. M. (1986). Increasing Returns and Long-Run Growth. Journal of Political Economy, 94(5), 1002-1037.

Romer, P. M. (1987). Growth Based on Increasing Returns Due to Specialization. American Economic Review, 77(2), 56-62. Retrieved from http://www.jstor.org/ stable/1805429

Romer, P. M. (1990). Endogenous Technological Change. Journal of Political Economy, 98(5), 71-102.

Romer, P. M. (1994). The origins of Endogenous Growth. Journal of Economic Perspectives, 8(1), 3-22.

Salonius, H., \& Lönnqvist, A. (2012). Exploring the Policy Relevance of National Intellectual Capital Information. Journal of Intellectual Capital, 13(3), 331-342. doi:10.1108/14691931211248891 
Schiuma, G., Lerro, A., \& Carlucci, D. (2008). The Knoware Tree and the Regional Intellectual Capital Index: An Assessment within Italy. Journal of Intellectual Capital, 9(2), 283-300. doi:10.1108/14691930810870346

Schumpeter, J. A. (1942). Capitalism, Socialism, and Democracy. New York: Harper.

Solow, R. (1957). Technical Change and the Aggregate Production Function. Review of Economics and Statistics, 39(3), 312-320.

Ståhle, P. (2008). National Intellectual Capital as an Economic Driver - Perspectives on Identification and Measurement. Inspired by Knowledge in Organizations, Swedish School of Economics and Business Administration, Helsinki, 94-121.

Ståhle, P., \& Bounfour, A. (2008). Understanding Dynamics of Intellectual Capital of Nations. Journal of Intellectual Capital, 9(2), 164-177. doi:10.1108/14691930810870283

Stam, C., \& Andriessen, D. (2009). Intellectual Capital of the European Union 2008: Measuring the Lisbon Strategy for Growth and Jobs. Electronic Journal of Knowledge Management, 7(4), 489-500.

Sullivan, P. H., \& Sullivan, P. H. (2000). Valuing Intangibles Companies: An Intellectual Capital Approach. Journal of Intellectual Capital, 4(1), 328-340. doi:10.1108/14691930010359234

Viedma Marti, J. M., \& Cabrita, M. R. (2012). Entrepreneurial Excellence in the Knowledge Economy: Intellectual Capital Benchmarking Systems. Basingstoke: Palgrave Macmillan.

Vlada RS. (2011). Strategija razvoja intelektualne svojine za period od 2011. do 2015. godine. Beograd: Vlada RS.

Weziak, D. (2007). Measurement of National Intellectual Capital: Application to EU Countries. IRISS Working Papers 2007-13. Differdange, Luxembourg: CEPS/ INSTEAD.

Wilson, R. A., \& Briscoe, G. (2004). The Impact of Human Capital on Economic Growth: A Review. In P. Descy, \& M. Tessaring (Eds.), Impact of Education and Training (Third report on vocational training research in Europe: background report) (pp. 9-70). Cedefop Reference series, 54. Luxembourg: Office for Official Publications of the European Communities. 